\title{
Pengaruh Perilaku Birokrasi Komisi Pemilihan Umum Terhadap Partisipasi Politik Masyarakat dalam Pemilihan Presiden dan Wakil Presiden Tahun 2014
}

\author{
Sandrianto Mamba Ari ',Andi Majidi², Muhammad Rais Rahmat ${ }^{3}$, Jamaluddin Ahmad ${ }^{4}$ \\ Magister Administrasi Publik, Sekolah Tinggi Ilmu Sosial dan Ilmu Politik Muhammadiyah Rappang \\ Sidenreng Rappang, Indonesia \\ Andimajidi4@gmail.com, mraisrahmat@yahoo.com, jahmadlado@yahoo.co.id.
}

\begin{abstract}
Abstrak - Tujuan penelitian ini adalah menjelaskan pengaruh perilaku birokrasi Komisi Pemilihan Umum Kabupaten Enrekang terhadap partisipasi politik masyarakat dalam pemilihan umum presiden dan wakil presiden tahun 2014 di Kabupaten Enrekang. Permasalahan pokok yang dianalisis dalam penelitian ini adalah (i) Untuk menganalisis pengaruh perilaku birokrasi Komisi Pemilihan Umum Kabupaten Enrekang terhadap partisipasi politik masyarakat pada Pemilihan Umum Presiden dan Wakil Presiden di Kabupaten Enrekang ; (ii) Untuk menganalisis faktor-faktor apasaja yang mempengaruhi perilaku birokrasi Komisi Pemilihan Umum Kabupaten Enrekang pada Pemilihan Umum Presiden dan Wakil Presiden di Kabupaten Enrekang ; (iii) Untuk menganalisis dampak partisipasi masyarakat dalam Pemilihan Umum Presiden dan Wakil Presiden di Kabupaten Enrekang. Penelitian ini menggunakan tipe penelitian kuantitatif deskriptif. Penelitian ini menggunakan metode explanatory survey atau penelitian penjelasan yang dilakukan melalui teknik survei.Populasi dalam penelitian ini sebanyak 4.254 orang penyelenggara pemilu di kabupaten enrekang dan pemilihan sampel dengan menggukan rumus slovin yaitu sebanyak 98 orang sampel. Variabel bebas dalam penelitian ini adalah perilaku birokrasi, dan variabel terikat adalah partisipasi politik masyarakat. Untuk mengetahui hasil penelitian ini, pengambilan data menggunakan kuesioner dengan tabel frekuensi, regresi linear sederhana dengan pengukuran skala linkert dengan bantuan SPSS versi 23 for windows. Hasil penelitian ini menunjukkan bahwa analisis deskriptif table frekuensi tanggapan responden terhadap perilaku birokrasi Komisi Pemilihan Umum dalam pelaksanaan Pemilihan Umum Presiden dan Wakil Presiden Tahun 2014 menujukkan: Perilaku individu 71,66\%; Perilakukelompok 80,66\%; danPerilakuorganisasi $70,04 \%$. Sedangkan nilai kumultaif sebanyak 74, $12 \%$. Demikian juga analisis statistic regresi linier sederhana menggambarkan $\mathbf{7 0 , 3 0 \%}$ kemampuan variable perilaku birokrasi Komisi Pemilihan Umum (X) menjelaskan variable partisipasi masyarakat $(Y)$. Dalam hal ini dapat diartikan bahwa variabel $X$ berpengaruh secara signifikan terhadap variabel $Y$ dan uji $T$ pada taraf kepercayaan 0,05 yaitu: $T$ hit $3,33>T$ tabel 2.16 dengan probabilitas 0,000000 . Menunjukkan bahwa semakin baik perilaku birokrasi yang dimiliki penyelenggara pemilu, maka dapat meningkatkan partisipasi politik masyarakat dalam pemilihan umum.
\end{abstract}

Kata kunci : Perilaku Birokrasi, Partisipasi Politik

\section{PENDAHULUAN}

Pemerintah merupakan manifestasi dari kehendak rakyat, karena itu harus memperhatikan kepentingan rakyat dan melaksanakan fungsi rakyat melalui proses dan mekanisme pemerintah. Untuk melakukan fungsi pemerintah tersebut, pemerintah melakukan aktivitas pelayanan, pengaturan, pembinaan, koordinasi, pengelolaan dan pembangunan dalam berbagai bidang kehidupan. Proses pelayanan masyarakat harus disertai dengan proses pemberdayaan lembaga dan aparat sehingga mampu memberikan layanan yang dianggap baik oleh masyarakat sebagai yang diperintah. Perbincangan tentang birokrasi pemerintah tidak pernah habishabisnya, kesannya tidak pernah efesien, terlalu lamban, tidak adaptif, berbelit-belit, tidak memberdayakan dan sebagainya. Kalau dapat dipersulit, kenapa harus dipermudah? Kalau dapat diperlambat, kenapa harus dipercepat? Kalau dapat memperdayakan, kenapa harus memberdayakan? Begitulah ungkapan yang berkembang yang menggambarkan kinerja (performance) birokrasi.

Komisi Pemilihan Umum adalah lembaga konstitutional independen yang bertanggung jawab untuk menyelenggarakan pemilihan umum nasional dan lokal sebagaimana diamanatkan oleh Undang-Undang Nomor I5 Tahun 20II, perlu menetapkan tahapan, regulasi atau aturan-aturan terkait pemilihan umum, agar pesta demokrasi dapat berjalan tertib, aman, jujur dan adil. Partisipasi masyarakat pun perlu diatur dalam Peraturan KPU guna menjamin pelaksanaan hak asasi manusia dalam penyelenggaraan pemilihan umum, Warga Negara Indonesia yang telah memenuhi syarat sebagai pemilih dijamin untuk dapat berpartisipasi dalam Pemilihan Umum tanpa adanya diskriminasi baik secara politik maupun suku, ras, agama maupun golongan. Undang-Undang Nomor 22 Tahun 2007 tentang Penyelenggara Pemilihan Umum yang kemudian disempurnakan melalui Undang-Undang Nomor I5 Tahun 20II dalam Pasal I angka (I) dikatakan bahwa Pemilihan Umum, selanjutnya disingkat Pemilu, adalah sarana pelaksanaan kedaulatan rakyat yang diselenggarakan secara langsung, umum, bebas, rahasia, jujur, dan adil dalam Negara Kesatuan Republik Indonesia berdasarkan Pancasila dan Undang-Undang Dasar Negara Republik Indonesia Tahun 1945. Sesuai Pasal 22 E ayat 
UUD 1945, pemilihan umum diselenggarakan untuk memilih Dewan Perwakilan Rakyat (DPR), Dewan Perwakilan Daerah (DPD), Presiden dan Wakil Presiden serta Dewan Perwakilan Rakyat Daerah (DPRD). Sedang Pemilu Presiden dan Wakil Presiden diatur secara jelas dalam Undang-undang Republik Indonesia Nomor 42 Tahun 2008 Tentang Pemilihan Umum Presiden Dan Wakil Presiden.

Pemilu 2014 ini ada dua serangkaian pemilihan umum, dimana Pemilu pertama memilih anggota DPR, DPD dan DPRD atau lebih dikenal dengan pemilu legislatif yang diselenggarakan pada tanggal 9 April 2014 kemudian Pemilu kedua yaitu memilih Presiden dan Wakil Presiden yang dilaksanakan pada tanggal 9 Juli 20I4. Pemilihan Umum (Pemilu) adalah salah satu cara dalam sistem demokrasi untuk memilih wakil-wakil rakyat yang akan duduk di lembaga legislatif maupun eksekutif, serta salah satu bentuk pemenuhan hak asasi warga negara dibidang politik. Pemilu dilaksanakan untuk mewujudkan kedaulatan rakyat,sebab rakyat tidak mungkin memerintah secara langsung. Karena itu, diperlukan cara untuk memilih wakil rakyat dalam memerintah suatu negara selama jangka waktu tertentu. Masyarakat (warga negara) adalah komponen penentu berhasil atau tidaknya pelaksanaan pemilu.Karena pada dasarnya hanya kekuatan pemilih, masyarakatlah yang bisa menentukan nasib negara dan bangsa kedepan. Setiap warga negara, apapun latar belakangnya seperti suku, agama, ras, jenis kelamin, status sosial, dan golongan, mereka memiliki hak yang sama untuk berserikat dan berkumpul, menyatakan pendapat, menyikapi secara kritis kebijakan pemerintah dan pejabat negara. Hak ini disebut hak politik yang secara luas dapat langsung diaplikasikan secara kongkrit melalui pemilihan umum.

Sebagaimana Sudijono Sastroatmodjo (1995:67) katakan "bahwa partisipasi politik merupakan aspek penting dalam sebuah tatanan negara demokrasi, sekaligus merupakan ciri khas adanya modernisasi politik".Partisipasi politik merupakan salah satu indikator penting dalam suatu lingkup negara yang menganut sistem demokrasi. Artinya suatu negara baru bisa dikatakan sebagai negara demokrasi apabila pemerintah yang berkuasa memberi kesempatan yang seluas-luasnya kepada warga negara untuk berpartisipasi dalamkegiatan politik. Masalah partisipasi politik juga bukan hanya menyangkut watak atau sifat dari pemerintahan negara, melainkan lebih berkaitan dengan sifat dan karakter masyarakat suatu negara serta pengaruh yang ditimbulkannya.

Keikutsertaan warga negara dalam pemilu merupakan serangkaian kegiatan membuat keputusan, yakni apakah memilih atau tidak memilih dalam pemilu.Keputusan untuk tidak memilih pada saat pemilu juga merupakan kategori dalam partisipasi politik. Karena menurut Milbarth dan Goel ketegori masyarakat yang apatis atau yang berarti tidak berpartisipasi dan menarik diri dari proses politik juga merupakan partisipasi politik. Keterlibatan masyarakat dalam partisipasi politik juga dapat menunjukkan perilakubirokrasi terhadap penyelenggara demokrasi. Perilaku birokrasi sangat mempengaruhi tingkat partisipasi politik masyarakat dalam memilih dan mengambil bagian dalam pesta demokrasi. Keberhasilan suatu demokrasi merupakan wujud dari interaksi antara pemerintah dengan rakyat dalam proses pembuatan, pelaksanaan dan penegakan segala hal yang menyangkut dan berhubungan dengan pengambilan keputusan untuk proses politik.

Partisipasi merupakan salah satu aspek penting dari demokrasi. Asumsi yang mendasari demokrasi (partisipasi) merupakan orang yang paling tahu tentang apa yang baik bagi dirinya adalah orang itu sendiri. Karena keputusan politik yang dibuat dan dilaksanakan oleh pemerintah menyangkut dan mempengaruhi kehidupan warga negara, maka warga masyarakat berhak ikut serta menentukan isi keputusan yang mempengaruhi hidupnya dalam keikutsertaan warga negara dalam mempengaruhi proses pembuatan dan pelaksanaan keputusan politik. Kegiatan warga negara biasa dibagi dua, yaitu mempengaruhi isi kebijakan umum dan ikut menentukan pembuatan serta pelaksana keputusan politik.

Kesadaran politik warga negara menjadi faktor determinan dalam partisipasi politik masyarakat, artinya sebagai hal yang berhubungan pengetahuan dan kesadaran akan hak dan kewajiban yang berkaitan dengan lingkungan masyarakat dan kegiatan politik menjadi ukuran dan kadar seseorang terlibat dalam proses partisipasi politik. Pengalaman pemilihan umum yang berlangsung dalam beberapa dekade menunjukkan banyaknya para pemilih yang tidak memberikan suaranya.Sebagai fenomena penggambaran di atas apabila seseorang memiliki kesadaran politik dan kepercayaan kepada pemerintah tinggi maka partisipasi pilitik cenderung aktif, sedangkan apabila kesadaran dan kepercayaan sangat kecil maka paritisipasi politik menjadi pasif dan apatis.

Komisi Pemilihan Umum (KPU) optimis partisipasi pemilih pada pemilu presiden 2014 meningkat, voter turn out lebih tinggi dibanding pileg dan pilpres 2009 angkanya di atas 75 persen,"sesuai dengan kutipan sambutan Komisioner KPU Ferry Kurnia Rizkiyansyah, di kantor KPU RI, Jakarta, Selasa 8 Juli 2014 dalam acara penyerahan laporan dana kampanye.(Sumber

http://www.republika.co.id/berita/nasional/politik//4/07/08/ n8e4qa-partisipasi-pemilih-pilpres-diprediksi-di-atas-75-

persen).Optimisme tersebut, menurut Ferry, Sosialisasi berjenjang yang dilakukan KPU mulai dari tingkat pusat sampai daerah, menurutnya disambut antusiasme tinggi dari masyarakat.

Namun terget tersebut belum dapat tercapai secara menyeluruh oleh penyelenggara pemilu di Indonesia, mulai dari KPU Pusat, Provinsi dan Kabupaten/Kota. Dapat kita lihat sejarah penyelenggaraan pemilu khususnya di Kabupaten 
Enrekang menunjukkan fakta terjadinya penurunan tingkat partisipasi pemilih.Dari sumber data arsip KPU Kabupaten Enrekang Tahun 20I4menunjukkan tingkat partisipasi pemilih di Kabupaten Enrekang dari tahun ke tahun menurun. Khususnya pada Pemilihan Umum Presiden pada tahun 2004 partisipasi pemilih menggunakan hak pilihnya mencapai $81 \%$, kemudian pada tahun 2009 mengalami penurunan yaitu pemilih yang menggunakan hak pilihnya $73 \%$, dan pada tahun 2014 Pemilihan Umum Presiden di Kabupaten Enrekang, mengalami penurunan drastis tingkat partisipasi masyarakat dalam menggunakan hak pilihnya yaitu hanya $68 \%$ dari pilih yang terdaftar di Kab. Enrekang sebanyak I5I.7I3 Pemilih.

Menurut sumber data KPU Provinsi Sulawesi Selatan partispasi pemilih Pemilu Presiden dan Wakil Presiden tahun 2014 di tingkat Kabupaten/Kota sebagai berikut: Kota Makassar 60\%, Gowa 72\%, Takalar 72\%, Jeneponto 58\%, Bantaeng 64\%, Selayar 71\%, Sinjai 66\%, Bone $70 \%$, Maros 69\%, Bulukumba $60 \%$, Pangkep 68\%, Barru 70\%, Soppeng 71\%, Wajo 65\%, Parepare 69\%, Sidrap 70\%, Enrekang 68\%, Luwu 73\%, Luwu Utara 69\%, Luwu Timur 66\%, Tana Toraja 67\%, Toraja Utara $66 \%$, Pinrang 67\%, dan Kota Palopo 62\%. Sedang persentase pemilih yang menggunakan hak pilihnya pada Pemilihan Umum Presiden dan Wakil Presiden tahun 2014 di Tingkat Kecamatan se-Kabupaten Enrekang, yaitu Kecamatan Maiwa 65\%, Enrekang 70\%, Baraka 70\%, Anggeraja 70\%, Alla 64\%, Bungin 72\%, Cendana 65\%, Curio 71\%, Malua 69\%, Buntu Batu $69 \%$, Masalle $61 \%$, Baroko $68 \%$, sehingga secara komulatif partisipasi politik di kabupaten enrekang hanya $68 \%$.

Meningkatnya angka pemilih yang tidak menggunakan hak pilihnya disebabkan oleh beberapa faktor diantaranya adalah Pertama, pemahaman masyarakat terhadap politik praktis yang masih rendah sehingga tidak berpikir rasional dan lebih memikirkan kepetingan jangka pendek.Kedua, pemilih pemula yang memiliki jumlah yang cukup signifikan yang sebagian besar baru memasuki hak pilih tidak memahami pengetahuan politik yang luas untuk menentukan ke mana mereka harus memilih.

Locus peneliti yaitu di Kabupaten Enrekangyang dimana merupakan salah satu Kabupaten di Provinsi Sulawesi Selatan yang memiliki kewajiban untuk menyelenggarakan kegiatan pemilu secara serentak dengan daerah-daerah lain sesuai dengan undang-undang demi mensukseskan demokrasi di negeri ini. Maksud pemilihan tempat penelitian tersebut karena disamping tempat domisili peneliti berada, juga merupakan kabupaten yang dalam wilayah Provinsi Sulawesi Selatan yang partisipasi politik masyarakatnya masih rendah pada Pemilihan Umum Presiden dan Wakil Presiden Tahun 2014 yaitu dibawah $75 \%$ tidak sesuai dengan harapan atau target dari Komisi Pemilihan Umum.

Menurut Skinner, seperti yang dikutip oleh Notoatmodjo (2003), merumuskan bahwa perilaku merupakan respon atau reaksi seseorang terhadap stimulus atau rangsangan dari luar. Oleh karena perilaku ini terjadi melalui proses adanya stimulus terhadap organisme, dan kemudian organisme tersebut merespons, maka teori Skinner ini disebut teori "S-OR" atau Stimulus - Organisme - Respon. Kemudian Stephen P. Robbins dan Timothy A. Judge (2008:II) menyatakan bahwa: "Perilaku organisasi (organizational behaviour) adalah sebuah bidang studi yang menyelidiki pengaruh yang dimiliki oleh individu, kelompok, dan struktur terhadap perilaku dalam organisasi, yang bertujuan menerapkan ilmu pengetahuan semacam ini guna meningkatkan keefektifan suatu organisasi. Robbins juga menjelaskan bahwa perilaku organisasi adalah studi yang mengambil pandangan secara mikro dan memberi tekanan pada individu-individu dan kelompok-kelompok kecil.Perilaku organisasi memfokuskan diri kepada perilaku di dalam organisasi dan seperangkat prestasi dan variabel mengenai sikap yang sempit dari para pegawai, dan kepuasan kerja adalah yang banyak diperhatikan".

Adapun Stephen P. Robbins (2003:3I) menjelaskan perilaku birokrasi timbul sebagai akibat interaksi antara karakteristik individu dengan karakteristik birokrasi, yang mengarah kepada pencapaian tujuan dalam organisasi. Salah satu fungsi birokrasi pemerintah yang utama adalah menyelenggarakan pelayanan umum sebagai wujud dari tugas umum pemerintahan untuk mewujudkan kesejahteraan masyarakat". Stephen P. Robbins mengembangkan model 3 (tiga) level dalam mempelajari perilaku manusia dalam organisasi melalui tiga tingkatan analisis yaitu:

I. Tingkatan Individu: karakteristik bawaan individu dalam organisasi.

2. Tingkatan Kelompok: dinamika perilaku kelompok dan faktor-faktor determinannya

3. Tingkatan Struktur Organisasi: faktor-faktor organizational yang mempengaruhi perilaku.

Ada (dua) 2 Variabel yang mempengaruhi Perilaku Organisasi, yaitu

I. Variabel Dependen dimana merupakan faktorfaktor kunci yang terpengaruh dari faktor lain, seperti : Produktivitas: organisasi dikatakan produktif jika ia mencapai sasarannya dan melakukannya dengan mentransfer input ke output dengan biaya terendah. Ukuran kinerja yang mencakup efektivitas dan efisiensi. , Keabsenan: tidak melapor untuk bekerja,Pengunduran diri: pengunduran diri sukarela maupun tidak dari organisasi, Perilaku warga organisasi: perilaku pilihan yang tidak menjadi bagian dari kewajiban kerja formal karyawan, namun mendukung berfungsinya organisasi tersebut secara efektif, Kepuasan Kerja: sikap umum individu terhadap pekerjaannya.

2. Variabel Independen merupakan dugaan penyebab dari sejumlah perubahan variabel dependen. Yang terbagi dari tiga level menurut Stephen P. Robbins, yaitu : 
I). Level individu:

a) Ciri biografis.

b) Kepribadian dan emosi.

c) Nilai.

d) Sikap.

e) Kemampuan.

f) Persepsi.

g) Motivasi.

h) Pembelajaran Individu Pengambilan keputusan.

2. Level kelompok:
a) Komunikasi.
b) Konflik.
c) Kekuasaan dan politik.
d) Tim-tim kerja.
e) Struktur kelompok.
f) Pengambilan keputusan kelompok.
g) Kepemimpinan dan kepercayaan.

3. Level Sistem Organisasi:

a) Struktur dan desain organisasi.

b) Desain kerja dan teknologi.

c) Budaya Organisasi.

d) Kebijakan dan praktek SDM.

Dalam hal level individual, Abraham Maslow juga mengemukakan bahwa manusia memiliki lima tingkat kebutuhan hidup yang akan selalu berusaha untuk dipenuhi sepanjang masa hidupnya. Lima tingkatan yang dapat membedakan setiap manusia dari sisi kesejahteraan hidupnya, teori yang telah resmi di akui dalam dunia psikologi. Kebutuhan tersebut berjenjang dari yang paling mendesak hingga yang akan muncul dengan sendirinya saat kebutuhan sebelumnya telah dipenuhi. Setiap orang pasti akan melalui tingkatan-tingkatan itu, dan dengan serius berusaha untuk memenuhinya, namun hanya sedikit yang mampu mencapai tingkatan tertinggi dari piramida ini.

Adapun dimensi partisipasi yang dapat mempengaruhi partisipasi politik masyarakat dalam pemilihan umum seperti yang dikemukakan oleh James Rosenau yang dikutip dalam bukunya Jalaluddin Rakhmat yang berjudul Komunikasi Politik Khalayak dan Efek antaralain:

I. Gaya partisipasi

Gaya mengacu kepada baik apa yang dilakukan maupun bagaimana ia melakukan sesuatu kegiatan Seperti gaya pembicaraan politik (antara singkat dan bertele-tele),gaya umum partisipasi pun bervariasi .Adapun yang termasuk dalam gaya partisipasi sebagai berikut:

a) Langsung/wakilan, Orang yang melibatkan diri sendiri (actual) dengan hubungan yang dilakukan terus-menerus dengan figure politik dengan cara menelepon, mengirim surat, dan mengunjungi kantor pemerintah.Yang lain bertindak terhadap politikus, tetapi tidak bersama mereka, misalnya mereka memberikan suara untuk memilih pejabat pemerintah yang belum pernah dilihat atau ditemuinya.

b) Kentara/takkentara, Seseorang mengutarakan opini politik, hal itu bisa meningkatkan kemungkinan diperolehnya keuntungan material (seperti jika mendukung seorang kandidat politik dengan imbalan diangkat untuk menduduki jabatan dalam pemerintahan).

c) Individual/kolektif. Bahwa tekanan dalam sosialisasi masa kanak-kanak, terutama dalam kelas- kelas pertama sekolah dasar, adalah pada gaya partisipasi individuall (memberikan suara, mengirim surat kepada pejabat, dsb). Bukan pada memasuki kelompok terorganisasi atau pada demontrasi untuk memberikan tekanan kolektif kepada pembuatan kebijakan.

d) Sistematik/acak Beberapa individu berpartisipasi dalam politik untuk mencapai tujuan tertentu, mereka bertindak bukan karena dorongan hati, melainkan berdasarkan perhitungan, pikiran, perasaan, dan usul mereka utnuk melakukan sesuatu bersifat konsisten, tidak berkontradisi, dan tindakan mereka kesinambungan dan teguh, bukan sewaktu-waktu atau dengan intensitas yang berubah-ubah.

e) Terbuka/Tersembunyi. Orang yang mengungkapkan opini politik dengan terangterangan dan tanpa ragu-ragu, dan yang menggunakan berbagai alat yang dapat diamati untuk melakukannya, bergaya partisipasi terbuka.

f) Berkomitmen/Takberkomitmen. Warga Negara berbeda-beda dalam intensitas partisipasi politiknya. Orang yang sangat mendukung tujuan, kandidat, kebijakan, atau program bertindak dengan semangat dan antusias; cirri yang tidak terdapat pada orang yang memandang pemilihan umum hanya sebagai memilih satu orang dengan orang lain yang tidak ada bedanya.

g) Derita/kesenangan. Seseorang bisa menaruh perhatian politik dan melibatkan deritanya karena kegiatan politik itu sendiri merupakan kegiatan yang menyenangkan. Yang lain ingin mencapai sesuatu yang lebih jauh dari politik melalui partisipasi.

2. Motif partisipasi. Berbagai fakto rmeningkatkan atau menekan partisipasi politik. Salah satu perangkat factor itu menyangkut motif orang yang membuatnya ambil bagian. Motif-motif ini ,seperti gaya partisipasi yang diberikannya berbeda-beda dalam beberapa hal sebagai berikut:

a) Sengaja/taksengaja. Beberapa warganegara mencari informasi dan berhasrat menjadi berpengetahuan ,mempengaruhi suara legislator, atau mengarahkan kebijaksanaan pejabat pemerintahan.

b) Rasional/emosional. Orang yang berhasrat mencapai tujuan tertentu, yang dengan teliti mempertimbangkan alat alternative untuk mencapai tujuanitu, dan kemudian memilih yang paling menguntungkan dipandang dari segi pengorbanan dan hasilnya disebut bermotivasi rasional. 
c) Kebutuhanpsikologis/social. Bahwa kadangkadang orang memproyeksikan kebutuhan psikologis mereka pada objek-objek politik misalnya, dalam mendukung pemimpin politik karena kebutuhan yang mendalam untuk tunduk kepada autoritas, atau ketika memproyeksikan ketidak cukupannya pada berbagai kelas "musuh" politik yang dipersepsi-minoritas, Negara asing, atau politikus dari partai oposisi.

d) Diarahkan dari dalam/dariluar. Perbedaan partisipasi politik yang dengan motivasi batiniah dan motivasi social untuk berpartisipasi politik.

e) Berpikir/tanpa berpikir. Setiap orang berbeda dalam tingkat kesadarannya ketika menyusun tindakan politik. Perilaku yang dipikirkan meliputi interpretasiaktif dari tindakan seseorang dan perkiraaan konsekuensi tindakan itu terhadap dirinya dan orang lain.

3. Konsekuensi partisipasi seorang dalam politik( Rakhmat: 2000:127). Partisipasi politikyangdipikirkandaninterpretatif dibandingkan dengan

jenisyangkurangdipikirkandanlebihtanpadisadarimen imbulkan pertanyaan tentangapa konsekuensipartisipasibagi peran seseorangdalampolitikpada umumnya. Konsekuensi partisipasi seorang dalampolitik tersebut memiliki beberapahalantaralain:

a) Fungsional/disfungsional. Tidak setiap bentuk partisipasi mengajukan tujuan seseorang. Jika misalnya tujuan seorang warga negara adalah melaksanakan kewajiban Kewarganegaraan yang dipersepsi, maka pemberian suara merupakan cara fungsional untuk melakukannya.

b) Sinambung/terputus. Jika partisipasi politik seseorang membantu meneruskan situasi, program, pemerintah atau keadaan yang berlaku, maka konsekuensinya sinambung. Jika partisipasi itu mengganggu kesinambungan kekuatan yang ada, merusak rutin dan ritual, dan mengancam stabilitas, partisi pasi itu terputus.l

c) Mendukung/menuntut. Melalui beberapa tipe tindakan, orang menunjukan dukungan mereka terhadap rezim politik yang ada dengan memberikan suara, membayar pajak, mematuhi hukum, menyanyikan lagu kebangsaan, berikrar setia kepada bendera, dan sebagainya .Melalui tindakan yang lain mereka mengajukan tuntutan kepada pejabat pemeintahan-mengajukan tuntutan kepada pejabat pemerintahan.

Berdasarkan dimensi partisipasi politik diatas, bahwa dalam partisipasi politik orang mengambil bagian dalam politik dengan berbagai cara. Cara-cara itu berbeda-beda dalam tiga hal atau dimensi yakni: gaya umum partisipasi, motif partisipasi yang mendasari kegiatan mereka, dan konsekuensi berpartisipasi pada peran seseorang dalam politik.

\section{METODE PENELITIAN}

Jadi Penelitian ini menggunakan tipe penelitian deskriptif kuantitatif, dengan metode ini diharapkan dapat memberikan gambaran secara cermat, jelas dan objektif mengenai masalah yang sedang diteliti. Populasi dalam penelitian ini adalah jumlah keseluruhan aparatur sipil negara di kantor badan kepegawaian diklat daerah Kabupaten Enrekang, yang berjumlah 4254 orang, dengan jumlah sampel dengan tingkat kesalahan 10\%, jadi sampel dalam penelitian ini adalah sebanyak 98 orang responden.

Adapun tekhnik pengumpulan data yaitu wawancara, observasi, kuisioner, dan studi kepustakaan, sedangkan tekhnik analisis data yaitu analisis data secara deskriptif kuantitatif, uji kualitas data, uji asumsi klasik, dan model regresi linear berganda dengan bantuan SPSS.

\section{HASIL DAN PEMBAHASAN}

I. Pengaruh perilaku birokrasi terhadap terhadap partisipasi masyarakat.

Analisis regresi linier Sederhana dipergunakan untuk menguji hipotesis pengaruh perilaku birokrasi (X) Terhadap partisipasi masyarakat (Y), secara statistic hipotesis dapat dinyatakan sebagai berikut:

$\mathrm{HO}=$ hipotesis di tolak

$\mathrm{HI}=$ hipotesis di terima

Komputasi yang dilkukan dengan menggunakan regresi linier sederhana diperolehpersamaan regresi sebegai berikut:

$$
Y=4 I . I I I+0,2 I 33 X+E
$$

Berdasarkan koefisien regresi variavel bebas (X) dengan nilai bi, persamaan regresi dapat diartikan bahwa partisipasi masyarakat $(Y)$ bertambah sebanyak nilai nilai $X$, jika variabel lainnya dalam keadaan konstan. Untuk melihat keberartian koefisien regresi tersebut, dilakukan pengujian terhadap persamaan regresi guna mengetahui apakah persamaan tersebut dapat digunakan untuk menduga pengaruh perilaku birokrasi $(X)$ terhadap partisipasi masyarakat (Y). Dengan uji statistic (uji t), variabel bebas $(X)$ pada taraf signifikansi 0,05 berpengaruh terhadap variabel $Y$ dengan $t$ hit 3.33 dengan probabilitas 0,00000, maka persamaan tersbut "sangat nyata ( $t$ hit 3,33 > t tab 2,16) seperti data yang terekan. Hasil pengujian perhitungan menunjukkan koefisien determinan (R2) 0,7030 untuk variabel bebas, artinya hanya $70,30 \%$ variabel partisipasi masyarakat (Y) dijelaskan oleh variabel Perilaku birokrasi (X), sedangkang 29,70\% lainnya ditentukan oleh variabel lain yang tidak diamati dalam penelitian ini. Koefisien korelasi (R) 0,3।20 menunjukkan hubungan "sedang" antara variabel bebas dan tidak bebas dalam model regresi ini.

2. Faktor yang mempengaruhi perilaku birokrasi terhadap partisipasi masyarakat.

98 responden yang diberikan kuesioner untuk memberikan tanggapan terhadap pelaksanaan koordinasi vewrtikal antara atasan dengan bawahan, 
terlihat ada 96 responden atau97,95\% yang memberikan jawaban pada klasifikasi "setuju”, dan 2 responden atau 03,05\% yang memberikan jawaban pada klasifikasi "ragu-ragu”. Berdasarkan data tersebut, maka dinilai bahwa pelaksanaan koordinasi secara vertical antara atasan dengan bahawan belum berjalan secara konsisten dan efektif, karena pimpinan dalam hal ini hanya memberikan pengarahan, penjelasan tanpa memberikan pertimbanga-pertimbangan secara jelas dan kongkrit terhadap bawahan. Oleh karena itu dapat dipahami bahwa koordinasi adalah tindakan seorang pimpinan untuk mengusahakan terjadinya keselarasan, antara tugas dan pekerjaan yang dilakukan oleh seseorang atau bagian yang satu dengan bagian yang lain. Hal ini berarti pekerjaan akan dapat dilaksanakan secara efektif dan efisien. Jadi dapat disimpulkan bahwa koordinasi merupakan proses pengintegrasian tujuan dan aktivitas di dalam suatu organisasi atau organisasi agar mempunyai keselarasan di dalam mencapai tujuan yang ditetapkan, pengkoordinasian dimaksudkan agar para manajer mengkoordinir sumber daya manusia dan sumber daya lain yang dimiliki organisasi tersebut.

98 responden yang diberikan kuesioner untuk memberikan tanggapan terhadap pelaksanaan koordinasi horizontal antara pejabat yang selevel dalam sebuah organisasi terlihat ada 40 responden atau $40,81 \%$ yang memberikan jawaban pada klasifikasi "sangat setuju"; 56 responden atau57,I4\% yang memberikan jawaban pada klasifikasi "setuju"; dan ada 2 responen atau 03.05\% yang memberikan jawaban pada klasifikasi "ragu-ragu". Data tersebut membuktikan bahwa koordinasi horizontal yang dipilih dan disesuaikan dengan kebutuhan atau kondisi-kondisi tertentu yang diperlukan untuk melaksanakan tugas agar pencapaian tujuan tercapai dengan baik.Dalam hal ini Hasibuan (2006:86) berpendapat bahwa tipe koordinasi horizontal (Horizontal Coordinatiori) adalah mengkoordinasikan tindakan-tindakan atau kegiatankegiatan penyatuan, pengarahan yang dilakukan terhadap kegiatan-kegiatan dalam tingkat organisasi (aparat) yang setingkat.

98 responden yang diberikan kuesioner untuk memberikan tanggapan terhadap pelaksanaan koordinasi diagonal atau koordinasi lintas saluranterlihat ada 33 responden atau 33,68\% yang memberikan jawaban pada klasifikasi "sangat setuju", dan 63 responden atau 64,28\% yang memberikan jawaban pada klasifikasi "setuju". Koordinasi secara diagonal yang sangat penting untuk diefektifkan karena ketika seorang pejabat dari bidang lain membutuhkan data dari bidan lainnya, sedangkan pejabat tersbut tidak berada ditempat, maka yang haraus dilakukan adalah meminta kepada pejabata yang lebih rendah untuk memberikan data sebagaimana yang dibutuhkan. Koordinasi secara efektif maka ada beberapa manfaat yang didapatkan, sebagaimana yang diungkapkan oleh Hasibuan (2006:86) bahwa koordinasi penting dalam suatu organisasi, yakni: (I) Untuk mencegah terjadinya kekembaran pekerjaan; (2) pekerjaannya diselaraskan serta diarahkan untuk pencapaian tujuan organisasi; (3) sarana dan prasarana dimanfaatkan untuk mencapai tujuan; (4) semua tugas, kegiatan, dan pekerjaan terintegrasi kepada sasaran yang diinginkan. Jadi koordinasi sangat penting dalam mengarahkan para bawahan untuk mencapai tujuan yang sesuai dengan apa yang direncanakan organisasi.

98 responden yang diberikan kuesioner untuk memberikan tanggapan terhadap supervise yang dilakukan oleh atasan terhadap pekerjaan bawahan, terlihat ada 37 responden atau $37.75 \%$ yang memberikan jawaban pada klasifikasi "sangat setuju", dan 61 responden atau $62.25 \%$ yang memberikan jawaban pada klasifikasi "setuju". Sejalan dengan hal tersebut, gaya kepemimpinan supervise memiliki potensi kekuatan .oleh karena itu kepemimpinan dengan mengevaluasi efektivitas relatif untuk dua hasil tim: kinerja tim di-peran dan inovasi tim. Tim-peran kinerja sejauh mana tim menyelesaikan tujuan dan menghasilkan hasil yang diinginkan, diharapkan, atau yang diinginkan, Tim inovasi adalah pengenalan atau aplikasi oleh tim ide, proses, produk, atau prosedur yang baru untuk tim dan yang dirancang untuk berguna (Chatman \& Flynn, dalam Moenir, 2002L III) .

98 responden yang diberikan kuesioner untuk memberikan tanggapan terhadap pemberian pengaatrahan dari atasan kepada bawahan dalam melaksanakan tugas terlihat ada 47 responden atau 47.95\% yang memberikan jawaban pada klasifikasi "sangat setuju", dan 5 I responden atau 52,05\% yang memberikan jawaban pada klasifikasi "setuju". Oleh karena itu, kepemimpinan partisipatif, yang memberi masukan lebih banyak kepada bawahan terkait dengan pelaksanaan tugas. Sehubungan dengan kepemimpinan supervise, maka diharapkan pimpinan organisasi dapat meningkatkan kinerja pegawai melalui mekanisme motivasi komitmen organisasi. Rasa komitmen dapat dikembangkan melalui dua proses utama, yaitu: (I) pemimpin dengan menerapakan gaya supervisi; (2) Para pemimpin ini meningkatkan komitmen untuk tujuan-tujuan organisasi (Barrett, 1998 dalam Sigian, 2000; 76).

98 responden yang diberikan kuesioner untuk memberikan tanggapan terhadap pemberian petunjuk dari atasa kepada bawahan dalam rangka pelaksanaan pekerkjaan, terlihat ada 46 responden atau $46.95 \%$ yang memberikan jawaban pada klasifikasi "sangat setuju", dan 52 responden atau 53,05\%yang memberikan jawaban pada klasifikasi "setuju". Pebetukan komitmen organisasi sebagai kekuatan relatif identifikasi individu dengan dan keterlibatan dalam organisasi tertentu $\mathrm{Hal}$ ini memiliki tiga komponen dasar, yaitu: keyakinan kuat dan penerimaan tujuan organisasi dan nilai-nilai, kemauan untuk mengerahkan usaha yang cukup atas nama organisasi, dan niat yang kuat atau keinginan untuk tetap dengan organisasi (Mowday, Steers, dan Porter, 1979 dalam Siagian, 2000: 156).

3. Dampak partisipasi masyarakat dalam pelaksanaan pemilihan umum. 
Permasalahan dalam Pelaksanaan Pemilihan UmumDalam setiap pelaksanaan kegiatan tidak menutup kemungkinan terjadi permasalahan dalam kegiatan tersebut meskipun presentasinya sangat kecil.Seperti halnya dalam pproses pelaksanaan pemilihan umum juga mengalami berbagai permasalahan yang dihadapi. Beberapa permasalahan dalam pelaksanaan pemilihan umum tersebut anatara lain:

a) Biaya yang mahal. Diakui bahwa pelaksanaan pemilihan umum di Indonesia masih sangat mahal hanya untuk menyelenggarakan pesta demokrasi tersebut. Hal ini dikarenakan proses pemilihan umum di Indonesia masih manual. Berbeda dengan Negara maju yang dalam proses pemiliohan umum sudah menggunakan teknologi canggih sehingga pelaksanaannya dapat lebih efisien dan efektif. Misalnya saja biaya pemilihan umum walikota palangka raya yang menhabiskan dana mencapai total angka Rp. 19,4 miliar lebih dengan rincian 10.3 $M$ untuk putaran pertama, dan jika terjadi pemungutan suara putaran kedua telah disiapkan dana sebesar Rp. 5.7 M. Disamping itu, Pemko juga telah mempersiapkan anggaran jika terjadi Pemungutan Suara Ulang (PSU) sebesar Rp. 3.5 M. KPU Kota Palangka Raya tidak mau berspekulasi jika terjadi hal-hal yang tidak diinginkan dalam pelaksanaan nanti, sehingga kami mengusulkan agar disiapkan anggaran untuk mengantisipasi jika terjadi PSU.

b) Golput. Golput atau golongan putih merupakan permasalahan yang sangat krusial karena merupakan permasalahan yang sangat sulit dipecahkan. Dari sudut pandang hak asasi manusia ini merupakan hal yang tidak dilarang oleh pemerintah Indonesia, berbeda dengan Negara negara maju, warga Negara yang tidak mau menggunakan hak pilihnya akan dikenakan sanksi misalnya di Negara Australia dan Cina.

c) Penetapan daftar pemilih tetap. Permasalahan ini biasanya terjadi pada pemilih pemula yang belum memiliki KTP atau pemilih yang baru pindah dari daerah satu kedaerah lain sehingga dama mereka tidak tercantum dalam DPT. Persoalan ini harus diselesaikan dengan cepat oleh pemerintah karena ini dapat emnghambat hak seseorang untuk dapat brepartisipasi dalam pemilu. Salah satu terobosan pemerintah untuk mengatasi persoalan ini adalah dengan membuat E-KTP Nasional yang dapat digunakan di setiap daerah. Dengan demikian hak seseorang untuk turut serta dalam pesta demokrasi tidak akan terhambat lagi. Terkait pelanggaran dalam pelaksanaan pemilu beberapa pelanggaran pemilu yang sering terjadi di beberapa daerah, antara lain:

I) Kampanye hitam. Kampanye hitam Yaitu kampanye yang bersifat menjelek-jelekkan calon lain, mengadu domba, memfitnah, menyebarkan berita bohong, menghasut, mengajak untuk tidak memilih calon lain, mengajak untuk tidak memilih calon yang tidak seiman. Hal demikian sangat dilarang karena dapat merugikan calon lain. Selain dapat merugikan calon lain, kampanye seperti ini sangat tidak mendidik masyarakat untuk menjadi lebih cerdas dalam bersikap bijak dalam pemilihan umum.

2) Money politic (politik uang). Permasalahan pelanggran pemilu yang satu ini sudah seperti menjadi budaya karena terlalu banyak calon yang melakukan hal ini.politik uang juga merupakan tindakan yang tidak adil karena hanya akan menguntungkan bagi calon yang memiliki harta banyak. Selain itu hal ini tidak memberikan pendidikan yang baik terhadap masyarakat dan cenderung membodohi masyarakat. Masyarakat harus lebih bijak dalam menyikapi hal ini Karena kebijakan selama satu periode tidak cukup terbayar dengan "serangan fajar" yang hanya berisi Rp. 50.000,- saja.

3) Kampanye yang tidak sesuai jadwal Meskipun KPU sudah merancang jadwal kampanye bagi setiap pasangan calon, tetapi masih ada saja pasangan calon yang curi start dalam pelaksanaan pemilu hal ini tentu sangat merugikan bagi pasangan lain. Selain itu hal tersebut rawan terjadi konflik karena banyaknya simpatisan yang berpotensi bentrok jadwal karena bertemu dijalan dan lain sebagainya. Selain kampanye tidak sesuai jadwal, banyak juga pasangan calon yang berkampanye di saran peribadatan dan saran pendidikan yang sudah jelas-jelas dilarang.

4) Intimidasi. Intimidasi pada masa kampanye merupakan hal terlarang karena hal ini sagat bertentangan dengan hak asasi manusia.Pelanggran ini biasanya berbentuk ancaman, tindak kekerasan, salah satu pasangan calon.Selain itu tindak pelanggaran ini juga bisa merusak/menghilangkan alat peraga pasangan lain.

5) Menggunakan fasilitas Negara Pelanggaran ini biasanya dilakukan oleh calon pasangan incumbent yang masih memiliki jabatan penting dalam pemerintahan. Hal paling sering dilakukan dengan menggunakan fasilitas Negara adalah intimidasi terhadap pegawai sampai dengan menggunakan anggaran Negara.

\section{KESIMPULAN}

Berdasarkan hasil analisis dan kajian terhadap pengaruh perilaku birokrasi Komisi Pemilihan Umun Kabupaten Enrekang terhadap Partsipasi Politik Masyarakat dalam pelaksanaan Pemilihan Umum Presiden dan Wakil Presiden Tahun 2014 di Kabupaten Enrekang dapat diungkapkan beberapa kesimpulan, sebagai berikut:

I. Hasil analisis deskriptif tabel frekuensi tanggapan responden terhadap perilaku birokrasi Komisi Pemilihan Umum Kabupaten Enrekang dalam pelaksanaanPemilihan Umum Presiden dan Wakil 
Presiden Tahun 2014 menujukkan: Perilaku individu 71,66\%; Perilaku kelompok 80,66\%; dan Perilaku organisasi $70,04 \%$. Sedangkan nilai kumultaif sebanyak $74,12 \%$.

2. Hasil analisis statistic regresi linier sederhana menggambarkan $70,30 \%$ kemampuan variabel perilaku birokrasi Komisi Pemilihan Umum Kabupaten Enrekang (X) menjelaskan variabel partisipasi politik masyarakat (Y). Dalam hal ini dapat diartikan bahwa variabel $X$ berpengaruh secara signifikan terhadap variabel $Y$ dan uji T pada taraf kepercayaan 0,05 yaitu: $\mathrm{T}$ hit 3,33 $>\mathrm{T}$ tabel 2.16 dengan probabilitas 0,000000 .

3. Faktor-faktor yang mempengaruhi perilaku birokrasi Komisi Pemilihan Umum Kabupaten Enrekang, yaitu sebagai factor pendukung: (a) dimensi koordinasi 87,41\%; dan (b) dimensi kepemimpinan $86,68 \%$

4. Dampak partisipasi masyarakat, yaitu: (a) pembangunan politik ; dan (b) penguatan nilai-nilai demokrasi.

\section{DAFTAR PUSTAKA}

[I] Ahmad, J. 20II. Perilaku Birokrasi dan Pengambilan Keputusan. Makassar: Badan Penerbit Universitas Negeri Makassar.

[2] Ahmad, J. 2015. (Metode Penelitian Administrasi Publik)Teori dan Aplikasi. Yogyakarta: Penerbit Gava Media.

[3] Santosa, Pandji. 2008. (AdministrasiPublik) Teori dan aplikasi good governance. Bandung: PT Refika Aditama.

[4] Mangkunegara, Anwar Prabu. 2005.Perilaku dan budaya organisasi. Bandung: PT Refika Aditama.

[5] Thoha, Miftah. 20II. Birokrasi pemerintah Indonesia di era reformasi. Jakarta: Kencana Prenada Media Group.

[6] Moenir. 2010. Manajemen pelayanan umum di Indonesia. Jakarta: PT Bumi Aksara.

[7] Natsir, Nanat Fatah. 2010. Moral dan etika elite politik. Yogyakarta: Pustaka Pelajar.

[8] Arifin, Indar. 20I0. Birokrasi pemerintahan dan perubahan social politik. Makassar: Pustaka Refleksi.

[9] Robbins Stephen. 20I5. Perilaku organisasi (Organizational behavior). Jakarta: Salemba Empat.

[10] Winardi. 2004. Manajemen perilaku organisasi. Jakarta: Kencana Prenada Media Group.

[II] Riani, Asri Laksmi. 20II. Budaya organisasi. Yogyakarta: Graha Ilmu. Djatmiko, Yayat Hayati. 2008. Perilaku organisasi. Bandung: Alfabeta.

[12] Tyson, Shaundkk. 2000. The essenceof organization behavior/Perilaku organisasi. Yogyakarta: Andi.

[13] Sopiah.2008. Perilaku organisasi. Yogyakarta: Andi.

[14] Indrawijaya, Adamlbrahim. 2010. Teori, perilaku, dan budaya organisasi. Bandung: PT Refika Aditama.

[15] Albrow, Matin.2004. Birokrasi. Yogyakarta : Tiara Wacana

[16] Ardana, Komangdkk. 2009. Perilaku keorganisasian. Yogyakarta:
Graha IImu. Blau,

[17] Peter dkk. 1987. Birokrasi dalam masyarakat modern. Jakarta: Penerbit UIPress, Salemba Empat.

[18] Kasiram.2008.Metodologi penelitian kualitatif kuantitatif.Malang: UIN Malang Press.

[19] Masyhuri. 2008. Metodologi pendekatan praktis dan aplikatif. Bandung: PT Refika Aditama.

[20] Sarwono, Jonathan. 2006. Metode penelitian kuantitatif dan kualitatif. Yogyakarta: Graha IImu.

[2I] Sinambela, Lijan Poltak, dkk. 20I0. Reformasi pelayanan public (Teori, Kebijakan, dan Implementasi). Jakarta: PT Bumi Aksara.

[22] Thoha, Miftah. 2005. Perilaku Organisasi, Konsep dasar dan aplikasinya. Jakarta:PT Raja grafindo persada.

[23] Thoha, M if t a h .2002. Perspektif perilaku birokrasi. Jakarta: PT Raja grafindo persada. 
